\title{
Immigration-related mental health disorders in refugees 5-18 years old living in Turkey
}

\author{
This article was published in the following Dove Press journal: \\ Neuropsychiatric Disease and Treatment \\ 10 November 2017 \\ Number of times this article has been viewed
}

\author{
Șermin Yalın Sapmaz' \\ Bengisu Uzel Tanrıverdi \\ Masum Öztürk' \\ Özge Gözaçanlar' \\ Gülsüm Yörük Ülker² \\ Yekta Özkan' \\ 'Department of Child and Adolescent \\ Psychiatry, ${ }^{2}$ Department of \\ Psychology, Faculty of Medicine, Celal \\ Bayar University, Manisa, Turkey
}

Purpose: This study assessed early-onset psychiatric disorders and factors related to these disorders in a group of refugee children after immigration due to war.

Materials and methods: This study was conducted between January 2016 and June 2016. Clinical interviews were conducted with 89 children and their families, and were performed by native speakers of Arabic and Persian who had been primarily educated in these languages and were living in Turkey. A strengths and difficulties questionnaire (SDQ) that had Arabic and Persian validity and reliability was applied to both children and their families. Independent variables for cases with and without a psychiatric disorder were analyzed using the $\chi^{2}$ test for categorical variables, Student's $t$-test for those that were normally distributed, and Mann-Whitney $U$-test for data that were not normally distributed. Data that showed significant differences between groups who had a psychiatric disorder and on common effects in emerging psychiatric disorders were analyzed through binary logistic regression analysis.

Results: A total of 89 children and adolescents were interviewed within the scope of the study. The mean age of cases was $9.96 \pm 3.98$ years, and $56.2 \%(n=50)$ were girls, while $43.8 \%$ $(n=39)$ were boys. Among these children, 47 (52.8\%) had come from Syria, 27 (30.3\%) from Iraq, 14 (15.7\%) from Afghanistan, and 1 (1.1\%) from Iran. A psychiatric disorder was found in $44(49.4 \%)$ of the children. A total of 26 children were diagnosed with anxiety disorders, 12 with depressive disorders, 8 with trauma and related disorders, 5 with elimination disorders, 4 with attention deficit/hyperactivity disorder, and 3 with intellectual disabilities. It was determined that seeing a dead or injured person during war/emigration and the father's unemployment increased the risk of psychopathology. The OR was 7.077 (95\% CI 1.722-29.087) for having seen a dead or injured individual and 4.51 (95\% GA 1.668-12.199) for father's employment status.

Conclusion: Within the context of war and emigration, these children try to cope with the negative circumstances they experience prior to migration, as well as the despair they see their parents experience.

Keywords: young refugees, asylum seekers, mental health, risk factors

\section{Introduction}

Migration involves a psychosocial process that has prominent and permanent effects on an individual's identity, and may result in a deep sense of loss. ${ }^{1}$ Migration from the Middle East to neighboring countries and Europe, especially within the last 5 years, has caused many individuals to leave their home, family, habits, and dreams.

A refugee is defined by the United Nations High Commissioner for Refugees (UNHCR) as a person who flees across an international border because of a well-founded fear of being persecuted for reasons of race, religion, nationality, or membership of a particular social group or political opinion, and who is not able to seek or receive
Correspondence: Șermin Yalın Sapmaz Department of Child and Adolescent Psychiatry, Faculty of Medicine, Celal Bayar University, Yunusemre, Manisa 45।40, Turkey

Tel +905326459176

Email drserminyalin@hotmail.com (c) (7) (ㅇ) 2017 Yalin Sapmaz et al. This work is published and licensed by Dove Medical Press Limited. The full terms of this license are available at https://www.dovepress.com/terms.php cc. hereby accept the Terms. Non-commercial uses of the work are permitted without any further permission from Dove Medical Press Limited, provided the work is properly attributed. For permission for commercial use of this work, please see paragraphs 4.2 and 5 of our Terms (https://www.dovepress.com/terms.php). 
protection from their country of origin. The term "asylum seeker" refers to those awaiting a decision about their refugee status. Refugees are defined by specific legal criteria, whereas the term "asylum seekers" refers to all people requesting refuge outside their home country. ${ }^{2}$ According to UNHCR data, as of June 20, 2016, approximately 65.3 million people in the world had been forced to move out of their home. Among these, 21.3 million people have been under the aegis of UNHCR; half of these are children and asylum seekers. A total of $54 \%$ of refugees worldwide originate from three countries: Somalia (1.1 million people), Afghanistan (2.7 million people), and Syria (4.9 million people). ${ }^{3}$ Turkey has been the center of irregular migration processes and has served as a passage to Europe since 2011. According to the newest data from the UNHCR on refugees, the number fleeing the war in Syria has reached 4,185,000 individuals. It has also been stated that the majority of these individuals reside in Turkey at this time. Turkey has been a temporary home for 2.5 million individuals. ${ }^{4}$ Although many of these individuals are from Syria, Turkey also has immigrants from Iraq, Iran, and Afghanistan. In addition, many of the immigrants migrate with their entire family, and the majority of families have children.

Trauma related to migration has a lasting effect on refugees. This effect can be physical or psychiatric in nature, and strongly affects the self. ${ }^{5}$ Refugees have stressors derived from three different sources. Among these stressors, first is their experience while living in their own country, second are the difficulties they face during immigration, and third are the difficulties they must endure in their new country while trying to establish a life for themselves and their families. ${ }^{2}$ Leaving the caregiver before or during immigration, being exposed directly to violence or witnessing violence, observing parents' panic and fear, and a lack of feeding possibilities are included in these stressors. Unemployment of the parents upon migration, low socioeconomic status, language issues, discrimination, cultural conflicts, and physical and psychiatric problems in parents are among factors that affect the well-being of children. ${ }^{6}$ Along with the effects of trauma, stress caused by uncertainties about their current condition and the future can lead to the development of psychiatric problems in refugees. ${ }^{?}$

At this time, previous studies have indicated that refugee children and adolescents are at risk of psychiatric problems. Bronstein and Montgomery reviewed studies that assessed psychological distress in refugee children living in Western countries in 2003-2008. In total, 3,003 children from 40 countries were evaluated. This study showed that post-traumatic stress-disorder rates were $19 \%-54 \%$, while depression was 3\%-30\% in refugee children; other emotional and behavioral problems also existed within the sample. ${ }^{8}$ Learning disorders, disruptions in school functioning, addiction, defiance, aggression, hyperactivity, feeding and sleeping problems, regressive behavior, nail-biting, enuresis, social retraction, and medically unexplained somatic symptoms have also been reported in refugee children. ${ }^{9-11}$

According to Turkey's refugee system, individuals who request asylum are directed to a city in the country, where they become residents while waiting for their applications to be processed. The city to which these individuals are directed is called a "satellite town". These towns provide refugees and asylum seekers residence during their stay in Turkey. The cities (62 satellite towns) for which residence permits would be given and refugees and asylum seekers would be located were determined in accordance with the regulations. Manisa has been one of the satellite towns determined in recent years. Since it is not one of the border towns with Syria, Iraq, or Iran, refugee settlement is generally under the control of the immigration authority. In satellite towns with borders on Middle East countries, being in an environment where the language of refugees is spoken by local people and being in a similar culture due to proximity to the region can be seen as characteristics increasing the adaptation of individuals. Socio-cultural structure of Manisa is different. Manisa is not one of Turkey's neighboring countries in the Middle East and language of refugees is not spoken by local people. The relative newness of this satellite city and providing controlled passage make refugees more accessible in Manisa. This accessibility has a facilitative effect in the development of adaptation-booster programs and fulfillment of various studies. As a result of the research carried out, Manisa has been chosen as an investigation area when data have been thought to have a contribution to the development of new programs on the basis of city. This study was designed by considering the unique location of Manisa. The first aim of this study was to assess immigration related mental health disorders of refugees between 5 to 18 years old living in Manisa. The second aim of the study was to investigate the relationship between psychiatric disorders and related factors such as traumatic experiences, presence of psychiatric and/ or physical problems prior to migration, sociodemographic features of their families.

\section{Materials and methods}

This study was of a cross-sectional nature, where data were derived from interviews conducted with war and refugee children and their families living in Manisa province between January 2016 and June 2016. According to immigrant-office 
headquarters data, the number of war and refugee children 0-18 years old living in Manisa and nearby villages was 298, of which 186 were school-age children 5-18 years old. Using the Epi Info computer program, the minimum sample size was calculated to be 86 ; when universal size was 186 , prevalence was $10 \%$ with a $95 \%$ CI and 5\% SE. The study was initiated after obtaining legal permission from the immigrant-office headquarters of the province and ethical approval from the local ethics committee of Celal Bayar University Medical School.

Initially, we contacted families using addresses obtained from the immigrant-office headquarters; however, on learning that the families had moved, refugee families who had applied to obstetrics and gynecology departments of the city hospitals were identified and contacted with two translators who help the families during their procedures at the hospital. Children and their families were assessed with a clinical interview based on Diagnostic and Statistical Manual of Mental Disorders (DSM)-IV diagnostic classification. To overcome the barriers of language between refugees and researchers, we used two translators who were native speakers of Arabic and Persian living in Turkey. As part of each interview, apart from the translators, at least two medical professionals who work within the field of child psychiatry were involved. For interviews with children and families who had migrated from Syria and Iraq, one child psychiatrist whose native language was Arabic also participated. As two families declined to participate, children from these families could not be assessed. In total, 42 families and 89 children aged 5-18 years, currently residing in Manisa, and who had migrated from Syria, Iraq, Iran, and Afghanistan were interviewed where they were living. The purpose of this study was explained to children and their families, and written consent was obtained from the parents. If parents were not able to read or write, verbal consent was provided. Sociodemographic data were compiled by researchers. A strengths and difficulties questionnaire was filled out by parents and children who were 11-18 years of age. Parents and children who did not know how to read or write were assisted by other staff members and translators in filling out the forms.

\section{Assessment tools}

\section{Kiddie schedule for affective disorders and}

Schizophrenia for school-age children: present

\section{and lifetime version}

This is a semistructured interview developed by Kaufman et al to evaluate present and lifetime psychopathology in children and adolescents according to DSM-III-R and DSM-IV criteria. ${ }^{12}$ In this study, mood disorders, anxiety disorders, post-traumatic stress disorder, obsessive-compulsive disorder, elimination disorders, disruptive behavior disorder, eating disorder, disorders related to substance abuse, psychotic disorders, and adjustment disorders were evaluated with clinical interviews.

\section{Sociodemographic data form}

Two separate sociodemographic data forms were used. The first form was used to assess descriptive features of the families (age of parents, education, current/past history of physical and/or psychiatric disorder, which country they had come from, the neighborhood and household conditions in Manisa, financial resources, how long they had been living in Manisa) and whether they had encountered traumatic experiences (Have they been exposed to maltreatment and torture during war? Have they seen any dead or injured person? Have they witnessed any type of shooting or bombing from the place they came from? Have they seen anyone being exposed to violence and killed? Have they witnessed anyone from their group get injured during war or migration? Has their family experienced any loss to date? Have they experienced being homeless or out of food anytime during war or migration? Have they been alone during war and migration? Have they any loved or close ones for whom they fear for their wellbeing in the country they have fled from? How do they feel about the ongoing war and negative circumstances, and do they see any ending to this?). The other form was designed for children, and was aimed at assessing the current academic status of the children, as well as whether they spoke Turkish and any past or current history of physical and psychiatric disorders.

\section{Strengths and difficulties questionnaire}

This questionnaire was developed by Robert Goodman in 1997, and consists of 25 questions that each assess behavioral features of both a positive and negative quality. ${ }^{13}$ The questionnaire consists of such subheadings as Attention deficiency and hyperactivity, Behavior problems, Emotional problems, Peer problems, and Social behavior. This instrument can be used to screen for psychiatric symptoms in children. The instrument's psychometric properties were assessed in Turkish, Arabic, and Persian. ${ }^{14}$ The questionnaire is commonly used in studies conducted with refugees. ${ }^{6,15}$

\section{Statistical analyses}

Statistical analysis of the study was performed using the SPSS 15.0 program. Descriptive data are presented as means $\pm \mathrm{SD}$, frequency, and percentage values. Sociodemographic data, traumatic experiences, school attendance, ability to speak 
Turkish, whether subjects showed any differences regarding scales applied, and medical histories for cases with and without a psychiatric disorder were analyzed using the $\chi^{2}$ test for categorical variables, Students' $t$-test for those that were normally distributed, and Mann-Whitney $U$-test for data that were not normally distributed. Dependent variables were psychiatric disorders in multivariate analyses. A separate model was not formed for every mental illness; all were gathered in one group and considered dependent variables. Data that showed significant differences between groups who had a psychiatric disorder and on common effects on emerging psychiatric disorders, were analyzed through binary logistic regression analysis. Statistical significance was set at $P<0.05$.

\section{Results}

Within the scope of the study, 89 children and adolescents who were victims of war and immigration were interviewed. Among these, 47 (52.8\%) originated from Syria, 27 (30.3\%) from Iraq, 14 (15.7\%) from Afghanistan, and 1 (1.1\%) from Iran. Interviewed children had been living in Turkey for $22.1 \pm 13$ months and for $18.8 \pm 13.3$ months in Manisa. Sociodemographic features of the children are presented in Table 1 and traumatic experiences presented in Table 2. Of the

Table I Sociodemographic data of participants $(n=89)$

\begin{tabular}{ll}
\hline Sociodemographic variables & $\mathbf{n}(\%)$ \\
\hline Age, years (mean \pm SD) & $9.96 \pm 3.98$ \\
Sex & \\
$\quad$ Girls & $50(56.2)$ \\
Boys & $39(43.8)$ \\
Mother's education & \\
$\quad$ Illiterate & $18(20.2)$ \\
Primary school (grades I-8) & $47(52.8)$ \\
High school/college & $24(27.0)$ \\
Father's education & \\
Illiterate & $15(16.9)$ \\
Primary school (grades I-8) & $38(42.7)$ \\
High school/college & $36(40.5)$ \\
Mother's current work status* & \\
Employed & $8(9.0)$ \\
Unemployed & $79(88.8)$ \\
Father's current work status* & \\
Employed & $52(58.4)$ \\
Unemployed & $31(34.8)$ \\
Socioeconomic status of neighborhood & \\
Low & $48(53.9)$ \\
Medium & $38(46.7)$ \\
High & $3(3.4)$ \\
Household conditions & \\
Bad & $46(51.7)$ \\
Goorage & $39(43.8)$ \\
\hline Note: Six & $4(4.5)$ \\
\hline
\end{tabular}

Note: *Six fathers and two mothers were dead at the time of the study.
Table 2 Data on traumatic experiences

\begin{tabular}{ll}
\hline Traumatic experiences & $\mathbf{n = 8 9}(\%)$ \\
\hline Loss within the family during this process & $82(92.1)$ \\
Witnessing violence directed toward a person or death & $74(83.1)$ \\
Witnessing shooting or bombing & $74(83.1)$ \\
Witnessing a dead or an injured person & $69(77.5)$ \\
People in their group getting injured during war and & $57(64.0)$ \\
immigration & \\
Being homeless and out of food during war and & $47(52.8)$ \\
immigration & $37(41.6)$ \\
Being exposed to maltreatment during war and & \\
immigration & \\
\hline
\end{tabular}

children, 44 (49.4\%) had a psychiatric disorder. A total of 26 children (29.2\%) had an anxiety disorder, 12 (13.5\%) had a depressive disorder, $8(9 \%)$ had a trauma and related disorder, $5(5.6 \%)$ had elimination disorder, $4(4.5 \%)$ had attention deficit/hyperactivity disorder, 3 (3.4\%) had mental retardation, and $1(1.1 \%)$ had autistic spectrum disorder. Anxiety disorders and nocturnal enuresis were comorbid diagnoses accompanying mental retardation and autism. When children with a psychiatric disorder and those without were compared for strengths and difficulties-questionnaire scores, we found that the emotional problems subscale $(P=0.001, P<0.0001)$ and hyperactivity subscale $(P=0.01, P=0.035)$, filled out by both children and parents, were significantly different. Cases with a psychiatric disorder showed higher scores within these subfields (Table 3). Appointments were given to children diagnosed with mental disorders and their parents. However, they did not show up.

Data that showed significant differences between groups who had and did not have a psychiatric disorder (Tables 4 and 5) regarding their common effects on emerging psychiatric disorders were analyzed through binary logistic regression analysis. Dependent variables were identified as psychiatric disorders, while independent variables were defined as father's educational level, which was significantly different between children with and without a psychiatric disorder, father's employment status, being homeless and out of food during war/immigration, witnessing a dead or injured individual, positive history in the family for a psychiatric disorder, positive history of a psychiatric disorder in the child, and age of the child. We found that witnessing an individual who was dead or injured during war/ immigration and current employment status of the father increased the probability of having a psychiatric disorder $(P=0.007, P=0.003)$ within this model. ORs were 7.077 (95\% CI 1.722-29.087) for having seen a dead or injured individual and 4.51 (95\% CI 1.668-12.199) for father's employment status (Table 6). 
Table 3 SDQ scores of refugees with and without psychiatric disorders

\begin{tabular}{|c|c|c|c|c|c|c|}
\hline \multirow[t]{2}{*}{ SDQ subscales } & \multicolumn{2}{|c|}{ Child notification, mean \pm SD } & \multirow[t]{2}{*}{$P$-value } & \multicolumn{2}{|c|}{ Parents notification, mean \pm SD } & \multirow[t]{2}{*}{$P$-value } \\
\hline & $\begin{array}{l}\text { Child with } \\
\text { psychiatric disorder }\end{array}$ & $\begin{array}{l}\text { Child without } \\
\text { psychiatric disorder }\end{array}$ & & $\begin{array}{l}\text { Child with } \\
\text { psychiatric disorder }\end{array}$ & $\begin{array}{l}\text { Child without } \\
\text { psychiatric disorder }\end{array}$ & \\
\hline Emotional problems & $5.77 \pm 2.3$ & $2.80 \pm 2.33$ & 0.001 & $5.48 \pm 2.57$ & $2.77 \pm 2.16$ & 0.0001 \\
\hline $\begin{array}{l}\text { Attention deficit/hyperactivity } \\
\text { problems }\end{array}$ & $4.13 \pm 2.41$ & $2.40 \pm 1.45$ & 0.010 & $4.48 \pm 2.51$ & $3.44 \pm 1.98$ & 0.035 \\
\hline Behavior problems & $2.27 \pm 2.22$ & $1.80 \pm 1.69$ & 0.492 & $2.27 \pm 2.22$ & $1.80 \pm 1.69$ & 0.492 \\
\hline Peer problems & $3.59 \pm 1.22$ & $2.80 \pm 1.26$ & 0.065 & $3.78 \pm 1.52$ & $3.26 \pm 1.72$ & 0.149 \\
\hline Social behavior skills & $8.81 \pm 1.13$ & $9.06 \pm 1.16$ & 0.523 & $7.97 \pm 2.45$ & $7.97 \pm 2.22$ & 0.997 \\
\hline Total score & $15.80 \pm 4.50$ & $9.80 \pm 4.90$ & 0.001 & $16.44 \pm 5.67$ & II. $.04 \pm 4.0$ & 0.001 \\
\hline
\end{tabular}

Abbreviation: SDQ, strengths and difficulties questionnaire.

\section{Discussion}

In this study, the frequency of psychiatric disorders in refugee children 5-18 years of age who had migrated from Syria, Iraq, and Afghanistan and who were currently living in Manisa was evaluated with affecting factors. In half of the children evaluated as a result of this study, psychiatric disorder was diagnosed, and it was found out that psychiatric disorder risk increased 7.1 times in children who had seen a dead or injured person during war/immigration. In addition, the

Table 4 Sociodemographic data on refugee children with and without psychiatric disorders in the context of war

\begin{tabular}{|c|c|c|c|c|}
\hline $\begin{array}{l}\text { Sociodemographic } \\
\text { variables }\end{array}$ & $\begin{array}{l}\text { Child with } \\
\text { psychiatric } \\
\text { disorder } \\
n=44(\%)\end{array}$ & $\begin{array}{l}\text { Child without } \\
\text { psychiatric } \\
\text { disorder } \\
\mathrm{n}=45 \text { (\%) }\end{array}$ & $\chi^{2}$ & $P$-value \\
\hline Sex & & & & 0.759 \\
\hline Girls & $24(48.0)$ & $26(52.0)$ & 0.094 & \\
\hline Boys & $20(5 \mathrm{I} .3)$ & $19(48.7)$ & & \\
\hline Age & & & & 0.044 \\
\hline$\geq 11$ years & $25(61.0)$ & $16(39.0)$ & 4.048 & \\
\hline$\leq 10$ years & $19(39.6)$ & $29(60.4)$ & & \\
\hline \multicolumn{4}{|c|}{ History of psychiatric disorders } & 0.020 \\
\hline Yes & $5(100)$ & 0 & 5.418 & \\
\hline No & $39(46.4)$ & $45(53.6)$ & & \\
\hline Mother's education & & & & 0.455 \\
\hline Illiterate & 7 (38.9) & II (6I.I) & 1.576 & \\
\hline Primary school & $26(55.3)$ & $21(44.7)$ & & \\
\hline High school/college & II (45.8) & $13(54.2)$ & & \\
\hline Father's education & & & & 0.042 \\
\hline Illiterate & $22(6 I . I)$ & 14 (38.9) & 6.345 & \\
\hline Primary school & $16(51.6)$ & $15(48.4)$ & & \\
\hline High school/college & $6(27.3)$ & $16(72.7)$ & & \\
\hline \multicolumn{4}{|c|}{ Psychiatric disorders in the family } & 0.040 \\
\hline Yes & $21(63.6)$ & $12(36.4)$ & 4.23 & \\
\hline No & $23(4 I . I)$ & $33(58.9)$ & & \\
\hline \multicolumn{4}{|c|}{ Father's current work status } & 0.011 \\
\hline Employed & $19(36.5)$ & $33(63.5)$ & 9.039 & \\
\hline Unemployed & $20(64.5)$ & II (35.5) & & \\
\hline Speaking Turkish & & & & 0.457 \\
\hline Yes & $20(45.5)$ & $24(54.5)$ & 0.552 & \\
\hline No & $24(53.3)$ & $21(46.7)$ & & \\
\hline
\end{tabular}

employment situation of the father increased mental disorder risk 4.5 times and was a distinctive factor in the mental health of refugee children.

Of the assessed children, $49.4 \%$ had a psychiatric disorder. Anxiety disorder, depressive disorder, trauma and related disorders, elimination disorders, attention deficit/hyperactivity disorder, mental retardation, and autism were among the diagnoses found in the children. Emotional problems subscale and attention deficit/hyperactivity problems

Table 5 Comparison of refugee children with and without psychiatric disorders related to traumatic experiences associated with war

\begin{tabular}{|c|c|c|c|c|}
\hline $\begin{array}{l}\text { Traumatic } \\
\text { experiences }\end{array}$ & $\begin{array}{l}\text { Child with } \\
\text { psychiatric } \\
\text { disorder } \\
n=44(\%)\end{array}$ & $\begin{array}{l}\text { Child without } \\
\text { psychiatric } \\
\text { disorder } \\
n=45(\%)\end{array}$ & $\chi^{2}$ & $P$-value \\
\hline \multicolumn{4}{|c|}{ Maltreatment during war and immigration } & 0.761 \\
\hline Yes & $19(51.4)$ & $18(48.6)$ & 0.093 & \\
\hline No & $25(48.1)$ & $27(5 \mid .9)$ & & \\
\hline \multicolumn{4}{|c|}{ Witnessing a dead or an injured individual } & 0.013 \\
\hline Yes & $39(56.5)$ & $30(43.5)$ & 6.163 & \\
\hline No & $5(25.0)$ & $15(75.0)$ & & \\
\hline \multicolumn{4}{|c|}{ Witnessing an individual being exposed to violence or killed } & 0.171 \\
\hline Yes & $39(52.7)$ & $35(47.3)$ & 1.872 & \\
\hline No & $5(33.3)$ & $10(66.7)$ & & \\
\hline \multicolumn{4}{|c|}{ Witnessing a shooting or bombing } & 0.423 \\
\hline Yes & $38(5 \mathrm{I} .4)$ & $36(48.6)$ & 0.643 & \\
\hline No & $6(40.0)$ & $9(60.0)$ & & \\
\hline \multicolumn{4}{|c|}{$\begin{array}{l}\text { People in their group getting injured during war or } \\
\text { immigration }\end{array}$} & 0.213 \\
\hline Yes & $31(54.4)$ & $26(45.6)$ & 1.553 & \\
\hline No & $13(40.6)$ & $19(59.4)$ & & \\
\hline \multicolumn{4}{|c|}{ Loss within the family during this process } & 0.250 \\
\hline Yes & $42(51.2)$ & $40(48.8)$ & 1.323 & \\
\hline No & $2(28.6)$ & $5(71.4)$ & & \\
\hline \multicolumn{4}{|c|}{$\begin{array}{l}\text { Being left homeless and out of food during war and } \\
\text { immigration }\end{array}$} & 0.043 \\
\hline Yes & $28(59.6)$ & $19(40.4)$ & 4.094 & \\
\hline No & $16(38.1)$ & $26(61.9)$ & & \\
\hline School attendance & & & & 0.152 \\
\hline Attending & $14(40.0)$ & $21(60.0)$ & 2.056 & \\
\hline Not attending & $30(55.6)$ & $24(44.4)$ & & \\
\hline
\end{tabular}


Table 6 Results of multiple regression analysis testing the impact of independent variables on psychiatric disorder

\begin{tabular}{llllll}
\hline Factors & $\beta$ & Wald & OR & $\mathbf{9 5 \%} \mathbf{C l}$ & $P$-value \\
\hline $\begin{array}{l}\text { Witnessing dead or } \\
\text { injured individual during } \\
\text { war/immigration }\end{array}$ & 1.506 & 8.804 & 7.077 & $1.722-29.087$ & 0.007 \\
$\begin{array}{l}\text { Current employment } \\
\text { status of the father }\end{array}$ & 1.957 & 7.364 & $4.5 \mathrm{I}$ & $\mathbf{1 . 6 6 8 - 1 2 . 1 9 9}$ & 0.003 \\
\hline
\end{tabular}

Note: Independent variables were father's educational level, father's employment status, being homeless and out of food during war/immigration, witnessing a dead or injured individual, positive history in the family for a psychiatric disorder, positive history of a psychiatric disorder in the child, and age of the child.

subscale scores of the strengths and difficulties questionnaire within the group with a psychiatric disorder were significantly higher. Previous studies have suggested that refugee children and adolescents are at risk of developing psychiatric problems. In a study conducted with 303 schoolage children in the UK, the scores of refugee children based on the strengths and difficulties questionnaire filled out by their teachers were much higher compared to those of children from two other control groups (from an ethnic minority who were not refugees and a group of English descent). ${ }^{16}$ The most common diagnosis in refugee children was post-traumatic stress disorder; however, depressive disorder and anxiety disorders were also common among this population. ${ }^{9}$ In a study conducted in the USA, upon clinical evaluation of 60 refugee children affected by war, it was seen that $30 \%$ had post-traumatic stress-disorder symptoms, $26.8 \%$ generalized anxiety disorder, $26.8 \%$ somatization, $21.4 \%$ traumatic bereavement, and $21.4 \%$ general behavioral problems. Comorbidity was also common. ${ }^{17}$ In a study of Yezidi children who had fled the war and lived in Turkey, $36.8 \%$ had depressive disorder, $28.9 \%$ conversion disorder, $21.8 \%$ adjustment disorder, $28.9 \%$ trauma-related disorder, $18.4 \%$ enuresis, and $10.5 \%$ separation-anxiety disorder. ${ }^{18}$ The results derived from this study are consistent with the results from other studies, showing that the psychiatric well-being of refugee children is at risk, which is supported by other relevant previous studies. ${ }^{916-18}$

The relationship between having a psychiatric diagnosis and being a refugee was assessed based on sociodemographic data, individual history, and family history of cases and traumatic events experienced. We found that children with a psychiatric diagnosis were older than 11 years, had psychiatric problems within the family history, had a previous psychiatric diagnosis, were left homeless and out of food during war/migration, witnessed a dead or an injured individual, had unemployed fathers and fathers with lower academic profile, and showed a relationship between meeting criteria for a psychiatric disorder and other variables. As a result of regression analysis, we found that having witnessed a dead or injured individual increased the risk of having a psychiatric disorder by 7.077-fold, while father being unemployed increased the risk by 4.51 -fold; other variables listed did not show statistical significance.

Refugees have stressors that originate from three different sources. The first of these is the difficulties they must endure while residing in their own countries, the second involves difficulties they experience during the migration process, and the third is difficulties they experience while they are trying to settle into their new lives in a foreign country. ${ }^{2}$ Being exposed to violence, separation from their caregivers, death of a parent, staying in a camp, going through starvation and drought during migration, witnessing parental despair and fear, unemployment of parents, financial difficulties, presence of psychiatric and physical illnesses in parents, unpredictable living conditions, difficulties regarding language, cultural conflicts, and being excluded from the society within the country they have migrated to are factors that have a negative effect on the psychiatric well-being of children. ${ }^{6,19}$

Different results in previous reports have been observed regarding age and psychiatric symptoms. Some studies have suggested a relationship between older age and psychiatric problems, while others have indicated a reverse association and others did not present any association at all. ${ }^{20-23}$ Age at onset of events, age at initiation of the migration process, the status of educational rights appropriate to age where the refugees have resided in, legal regulations, and parental loss are among factors that may be associated with such discrepancies. In our study, we found a higher rate of psychiatric disorders among children who were older, consistent with reports in the literature. ${ }^{23-26}$ This may be associated with various factors, such as long-term problems in the countries from which refugees originated. It is possible that older children experienced many traumatic events prior to migration, during the process, and after the process, which may have affected their psychosocial development. Older children might have been able to notice the periods they went through as a result of their cognitive development and how they could have been affected. In some cultures, it is common that older children within the family are expected to take on the role of a parent or adult if the family dissolves or experiences adverse events, which, in turn causes an increase in the psychiatric problems of the child.

In our study, we found that if fathers were less educated and had a positive history of psychiatric problems in the family, the children showed an increased risk of a psychiatric 
disorder, which agrees with previous reports. ${ }^{20,27-30}$ This is compatible with studies performed with refugees. ${ }^{19}$ Parents' education has been found to be effective in the severity and continuity of mental health issues in children. It has been stated that well-educated parents are more aware of child development: they can apply suitable attitudes supporting their growth and can reach appropriate centers when problems emerge. ${ }^{31}$ Therefore, the education of refugee parents is thought to be important for the mental health of their children.

For refugee children, being exposed to trauma related to war is a risk factor for psychopathology. In a meta-analysis of 7,920 children affected by war, $47 \%$ of children had posttraumatic stress disorder, $43 \%$ had depression, and 35\% had anxiety disorder. ${ }^{10}$ In a study where 93 refugee children aged 10-16 years in Norway were evaluated 6 months after settling in a new country, for violent life events and psychological symptoms they had encountered previously, $68 \%$ of participants had experienced death of a close relative or friend, $63 \%$ had witnessed violence, and $62 \%$ had lived through war. At the end of the study, violent life events were found to be associated with post-traumatic stress-disorder symptoms, anxiety disorders, and depression. ${ }^{32}$ In our study, cases had been directly affected by war and had gone through many traumatic experiences. Upon regression analysis, other variables lost their significance, and witnessing a dead or an injured person increased the odds of a psychiatric disorder by 7.077-fold. Being exposed directly to trauma, severity of trauma, and the perceived threat level affect psychological well-being. ${ }^{33}$ Trauma during war can be of an unexpected and sudden nature, often accompanied by traumatic scenery. Both children and adults who have been exposed to these events are negatively affected. The reason children have a higher risk of developing a psychiatric disorder following these events may be related to their losing hope about the future or overcoming famine, drought, or finding shelter with the aid of their parents. On the other hand, adults close to the child may not be able to control their reactions to death and injury, complicating age-appropriate explanations to the child.

Paternal employment and socioeconomic levels affect the psychiatric status of children. ${ }^{34-36}$ In our study, the father not having a job showed an increased risk of the child developing a psychiatric disorder by 4.51 -fold. Studies have implied that sociodemographic factors, such as low-level parent education and unemployment of parents, could predict psychiatric issues and violent behavior in children and teenagers. The development risk of mental disorders has been shown to be two or three times more in children and teenagers who are disadvantaged socioeconomically. ${ }^{31}$ The father not having a steady job may affect the family and the children negatively through not being able to meet feeding and household requirements, as well as not being able to access health facilities and basic needs. ${ }^{31,37}$ In addition, it may cause a strain on family relationships by creating disruptions in current life conditions and increasing anxiety over economic difficulties and coping skills, resulting in difficulties with regard to forming a positive and affectionate bond with children in the family.

Our study increases our understanding of the consequences of migration and being a refugee. Our results in the Manisa sample demonstrate the difficulties these people endure during migration and the effects of these processes on their children. Refugees that immigrated to our country have education and health rights. When they complete various approvals, they also have a right to employment. Although they have certain rights, they do not know about them adequately and have difficulty in finding accurate pathways to these ends. It is also noteworthy that though they were directed to our hospital polyclinics during our study, they did not show up. Problems for access to these rights and inadequate information lead to uncertainties and troubles in daily life. According to Carswell et al, policies developed by governments to sustain the well-being of refugees, as well as in many other public health domains, are important. ${ }^{38}$ At this time, emergent intervention plans regarding health, education, and shelter are required, and novel policies need to be implemented to prevent these problems from continuing. In addition, the status of the children should be assessed separately from their parents. Parents may migrate voluntarily or involuntarily; however, children are always "in exile": they are not the ones who have decided to leave, and they are not the ones who decide whether to return. ${ }^{1}$ From this perspective, children have to manage unfavorable circumstances prior to migration regarding the despair their parents experience, not being able to attend school, being liable to food shortages, and being unable to meet their own physical requirements. Unfavorable conditions for the parents affect the child, and the child's problems affect the parent. It is known that social support is an important protective factor. Positive physical and mental health, high academic or professional achievement, being able to talk in the language of the country resided in, and being able to obtain support when required are among the primary protective factors for the psychiatric well-being of refugee children and adolescents. ${ }^{38}$ Being able to engage in the social environment in a healthy way, being able to stay within their own ethnic community, and being able to 
live in a similar social, economic, and cultural condition as experienced in the previous country are important factors that aid in the adjustment of refugees. ${ }^{39}$

Our results indicate that refugee children try to overcome negative experiences prior to migration, the despair their parents experience, not being able to attend school, and not being able to meet their physical needs. In cases where judicious interventions are not made, this process can lead to serious psychosocial and social consequences. Therefore, we aimed to increase awareness of this matter while providing a basis for larger-scale studies and projects aimed at supporting refugee children.

\section{Disclosure}

The authors report no conflicts of interest in this work.

\section{References}

1. Akhtar S. Immigration and Identity: Turmoil, Treatment, and Transformation. Lanham (MD): Jason Aronson; 1999.

2. Pacione L, Measham T, Rousseau C. Refugee children: mental health and effective interventions. Curr Psychiatry Rep. 2013;15:341.

3. UN Refugee Agency. Figures at a glance. 2017. Available from: http:// www.unhcr.org/figures-at-a-glance.html. Accessed March 7, 2017.

4. UN Refugee Agency. UNHCR report highlights education crisis for refugee children. 2017. Available from: http://www.unhcr.org/turkey/ uploads/root/unhcr_turkey_operational_update_jan-june_2016.pdf. Accessed March 7, 2017.

5. Özen H. Trauma of Chechen refugee women living in Istanbul: meaning making and coping strategies [unpublished master's thesis]. Istanbul: Sabanci University; 2014.

6. Crowley $\mathrm{C}$. The mental health needs of refugee children: a review of literature and implications for nurse practitioners. J Am Acad Nurse Pract. 2009;21:322-331.

7. Goosen S, Stronks K, Kunst AE. Frequent relocations between asylum-seeker centres are associated with mental distress in asylumseeking children: a longitudinal medical record study. Int J Epidemiol. 2014;43:94-104.

8. Bronstein I, Montgomery P. Psychological distress in refugee children: a systematic review. Clin Child Fam Psychol Rev. 2011;14:44-56.

9. de Anstiss H, Ziaian T, Procter N, Warland J, Baghurst P. Helpseeking for mental health problems in young refugees: a review of the literature with implications for policy, practice, and research. Transcult Psychiatry. 2009;46:584-607.

10. Attanayake V, McKay R, Joffres M, Singh S, Burkle F Jr, Mills E. Prevalence of mental disorders among children exposed to war: a systematic review of 7,920 children. Med Confl Surviv. 2009;25:4-19.

11. Morgos D, Worden JW, Gupta L. Psychosocial effects of war experiences among displaced children in southern Darfur. Omega (Westport). 2007;56:229-253.

12. Kaufman J, Birmaher B, Brent D, et al. Schedule for affective disorders and schizophrenia for school-age children - present and lifetime version (K-SADS-PL): initial reliability and validity data. J Am Acad Child Adolesc Psychiatry. 1997;36:980-988.

13. Goodman R. Psychometric properties of the strengths and difficulties questionnaire. J Am Acad Child Adolesc Psychiatry. 2001; 40:1337-1345.

14. Youth in Mind. Downloadable SDQs and related items. 2015. Available from: http://www.sdqinfo.com/py/sdqinfo/b0.py. Accessed March 7, 2017.
15. Wiegersma A, Stellinga-Boelen AA, Reijneveld SA. Psychosocial problems in asylum seekers' children: the parent, child, and teacher perspective using the strengths and difficulties questionnaire. $J$ Nerv Ment Dis. 2011;199:85-90.

16. Fazel M, Stein A. Mental health of refugee children: comparative study. BMJ. 2003;327:297-309.

17. Betancourt TS, Newnham EA, Layne CM, et al. Trauma history and psychopathology in war-affected refugee children referred for traumarelated mental health services in the United States. J Trauma Stress. 2012;25:682-690.

18. Çeri V, Özlü-Erkılıç Z, Özer Ü, Yalçın M, Popow C, Akkaya-Kalaycı T. Psychiatric symptoms and disorders among Yazidi children and adolescents immediately after forced migration following ISIS attacks. Neuropsychiatr. 2016;30:145-150.

19. Fazel M, Reed VR, Panter-Brick C, Stein A. Mental health of displaced and refugee children resettled in high-income countries: risk and protective factors. Lancet. 2012;379:266-282.

20. Angel B, Hjern A, Ingleby D. Effects of war and organized violence on children: a study of Bosnian refugees in Sweden. Am J Orthopsychiatry. 2001;71:4-15.

21. Ellis BH, MacDonald HZ, Lincoln AK, Cabral HJ. Mental health of Somali adolescent refugees: the role of trauma, stress, and perceived discrimination. J Consult Clin Psychol. 2008;76:184-193.

22. Sourander A. Behavior problems and traumatic events of unaccompanied refugee minors. Child Abuse Negl. 1998;22:719-727.

23. Yurtbay T, Alyanak B, Abali O, Kaynak N, Durukan M. The psychological effects of forced emigration on Muslim Albanian children and adolescents. Community Ment Health J. 2003;39:203-212.

24. Hasanović M, Sinanović O, Pavlović S. Acculturation and psychological problems of adolescents from Bosnia and Herzegovina during exile and repatriation. Croat Med J. 2005;46:105-115.

25. Bean TM, Eurelings-Bontekoe E, Spinhoven P. Course and predictors of mental health of unaccompanied refugee minors in the Netherlands: one year follow-up. Soc Sci Med. 2007;64:1204-1215.

26. Nielsen SS, Norredam M, Christiansen KL, Obel C, Hilden J, Krasnik A. Organisational factors influencing asylum-seeking children's mental health. BMC Public Health. 2008;8:293.

27. Montgomery E. Long-term effects of organized violence on young Middle Eastern refugees' mental health. Soc Sci Med. 2008; 67:1596-1603.

28. Montgomery E. Trauma and resilience in young refugees: a 9-year follow-up study. Dev Psychopathol. 2010;22:477-489.

29. Smith P, Perrin S, Yule W, Rabe-Hesketh S. War exposure and maternal reactions in the psychological adjustment of children from BosniaHercegovina. J Child Psychol Psychiatry. 2001;42:395-404.

30. Almqvist K, Broberg AG. Mental health and social adjustment in young refugee children 31/2 years after their arrival in Sweden. J Am Acad Child Adolesc Psychiatry. 1999;38:723-730.

31. Reiss F. Socioeconomic inequalities and mental health problems in children and adolescents: a systematic review. Soc Sci Med. 2013; 90:24-31.

32. Jensen TK, Fjermestad KM, Granly L, Wilhelmsen NH. Stressful life experiences and mental health problems among unaccompanied asylumseeking children. Clin Child Psychol Psychiatry. 2015;20:106-116.

33. Ehntholt KA, Yule W. Practitioner review: assessment and treatment of refugee children and adolescents who have experienced war-related trauma. J Child Psychol Psychiatry. 2006;47:1197-1210.

34. Lustig S, Kia-Keating M, Knight W, et al. Review of child and adolescent refugee mental health. J Am Acad Child Adolesc Psychiatry. 2004;43:24-36.

35. Halcón LL, Robertson CL, Savik K, et al. Trauma and coping in Somali and Oromo refugee youth. J Adolesc Health. 2004;35:17-25.

36. Tousignant M, Habimana E, Biron C, Malo C, Sidoli-LeBlanc E, Bendris N. The Quebec Adolescent Refugee Project: psychopathology and family variables in a sample from 35 nations. J Am Acad Child Adolesc Psychiatry. 1999;38:1426-1432. 
37. Conger RD, Donnellan M. An interactionist perspective on the socioeconomic context of human development. Annu Rev Psychol. 2007;58: 175-199.

38. Carswell K, Blackburn P, Barker C. The relationship between trauma, post-migration problems and the psychological well-being of refugees and asylum seekers. Int J Soc Psychiatry. 2011;57:107-119.
39. Sağaltıcı E. Suriyeli mültecilerde travma sonrasi stres bozukluğu taraması [unpublished thesis]. Ankara: Gazi Universitesy; 2013.

\section{Publish your work in this journal}

Neuropsychiatric Disease and Treatment is an international, peerreviewed journal of clinical therapeutics and pharmacology focusing on concise rapid reporting of clinical or pre-clinical studies on a range of neuropsychiatric and neurological disorders. This journal is indexed on PubMed Central, the 'PsycINFO' database and CAS, and is the official journal of The International Neuropsychiatric Association (INA). The manuscript management system is completely online and includes a very quick and fair peer-review system, which is all easy to use. Visit http://www.dovepress.com/testimonials.php to read real quotes from published authors.

Submit your manuscript here: http://www.dovepress.com/neuropsychiatric-disease-and-treatment-journal 